\title{
Progressive osseous heteroplasia
}

INSERM

\section{Source}

INSERM. (1999). Orphanet: an online rare disease and orphan drug data base.

Progressive osseous heteroplasia. ORPHA:2762

Progressive osseous heteroplasia $(\mathrm{POH})$ is a rare genetic bone disorder characterized clinically by progressive extraskeletal bone formation presenting in early life with cutaneous ossification, that progressively involves subcutaneous and then subsequently deep connective tissues, including muscle and fascia. POH overlaps with a number of related genetic disorders including Albright hereditary osteodystrophy, pseudohypoparathyroidism (see these terms), and primary osteoma cutis, that share the common features of superficial heterotopic ossification in association with inactivating mutations of GNAS gene (20q13.2-q13.3), coding for guanine nucleotide-binding proteins. $\mathrm{POH}$ can, however, be distinguished clinically by the deep and prog ressive nature of the heterotopic bone formation. 